\title{
To Evaluate The Self-Apprehension Of Dental Students About Their Own Smile Aesthetics
}

Farzana Memon, Salwa Memon, Muhammad Muslim Khahro, Abdul Salam Memon

\section{ABSTRACT:}

Objective: This cross-sectional observational study was accomplished at Isra University to evaluate the self-apprehension of dental students related to their own smile.

Material and Methods: This study was comprised of 166 dental students belonging to both genders. A structured selfadministered questionnaire was used to conduct a survey among undergraduate dental students at all study levels in Isra University. Questionnaire was designed to observe the self-apprehension and satisfaction of students with reference to their dental appearance.

Data analysis was done using descriptive statistics via $21^{\text {st }}$ version of SPSS. $0.05 \%$ was established as the level of significance.

Results: 166 students (32 males and 134 females) participated in this survey. 32.5\% students were shy as against $91.6 \%$ students who were bold at smiling in public. $55.4 \%$ students preferred to be photographed from side pose while $69.9 \%$ were inspired by other's smile.

In terms of teeth dimensions, $60.2 \%, 54.8 \%$ and $46.4 \%$ students were gratified with the length, breadth and form of their teeth respectively.

Conclusion: This study concludes that greater number of dental student were self-assured regarding their apprehension on their own dental appearance. Majority of the females though contented with the dimensions and contour of their teeth, urged to have lighter teeth.

Key words: Self-apprehension, dental appearance, smile, dental students.

\section{INTRODUCTION:}

When we think of beauty, the immediate thought which strikes our mind is the face. The reason being for that is the face has a very important and attractive attribute called smile next to the eyes ${ }^{1,2}$; their significance indicated through studies as $31 \%$ and $34 \%$ respectively ${ }^{3-6}$.

As for now, dental aesthetics have become a necessity as there are people who are lacking self-assurance and becoming reserved as a consequence of not having a pleasant appearance ${ }^{7,8}$.

Smile as we know and as discussed earlier is very crucial

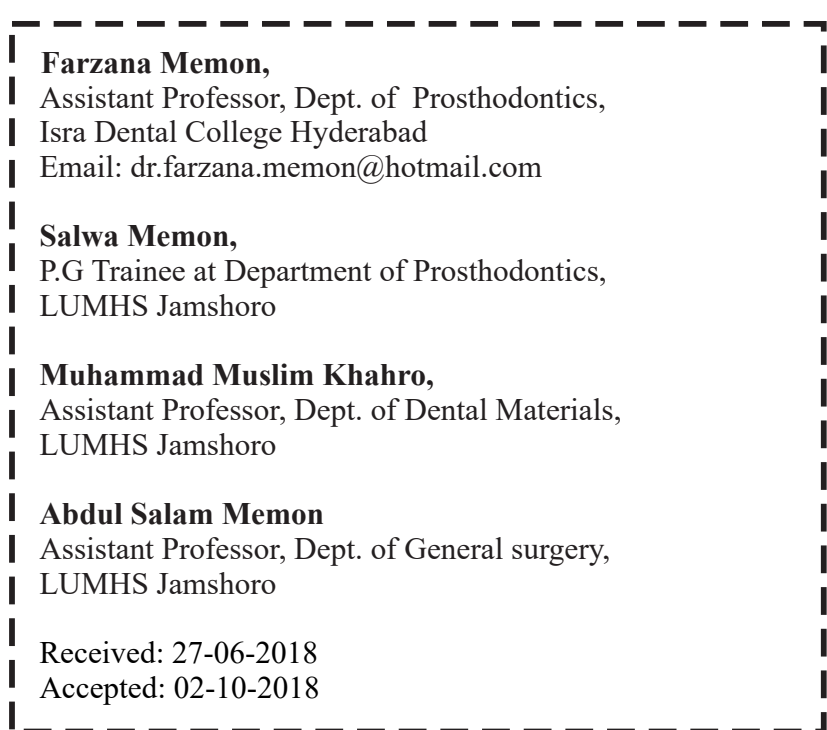

and thus many patients visit the dentists nowadays for orthodontic treatment and aesthetic restorations ${ }^{9-11}$. In recent times, significant dental aesthetics is consequential in creating pleasant and decent appearance, which in turn helps the patient regain their lost confidence ${ }^{12}$.

Media these days with advertisements and endorsements of beauty creams and tooth pastes manipulate the society and force them to become a physically well-being individual and so the fundamental objective of aesthetic dentistry is to make people look attractive by making their smile attractive. This explains why the demand of aesthetic dentistry has excelled in today's generation.

Aesthetic dentistry is recognized to create a satisfying smile in order to make people appear beautiful. In order to fulfil this task, the dentist must make a treatment plan based on the requirements of dental management and patient's aesthetic concerns.

Concept of smile aesthetics between a lay man and a dentist definitely differs. In a study ${ }^{13}$ conducted in the year 2016, Saffarpour A et al proved that difference in smile insight between these two is negligible and on the other hand, Tortopidis $\mathrm{D}^{14}$ remarked that the patient's expectations related to dental aesthetics are higher and un-realistic as compared to dentists. Few of the patients desire extensive aesthetic corrections regarding tooth form, colour and tooth position but dentists however, are more receptive to colour, contour and mastication of teeth ${ }^{15}$.

Dental Education imparts a great effect on the correct 
understanding and awareness of the basic concepts of dental aesthetics thus improving their own aesthetic apprehension. Though gaining much knowledge regarding aesthetics may cause the dental students discontented with their smile as they gain more and more awareness regarding smile aesthetic fundamentals which might go unnoticeable if looked otherwise, yet it might prevent the students from indulging into unrealistic desires leading to false look. Hence, the aim of this study is to appraise the self-concept of undergraduate dental students regarding their smile in terms of gratification.

\section{MATERIAL AND METHODS:}

This cross sectional observational study was executed on undergraduate dental students at Isra University to evaluate their self-apprehension regarding their own dental appearance. After getting consent from ethical committee and study participants a self-structured questionnaire was used to conduct a survey among undergraduate dental students. Of 210 total students, 166 (134 females and 32 males) agreed to participate in the study and filled the question form.

The survey form was divided into three set of questions, the first set of questions enclosed polar questions that interrogated about confidence at smiling in public places, contentment with the colour and contour of their teeth and gums and whether the participants esteemed someone's smile in public or media.

The other set of questions enquired regarding gratification with the dimensions of teeth, proportion of teeth to gums and incisal display.

The third set of questions encompassed a visual analogue scale $(0-10)$, where score 0 was measured as least satisfied while score 10 reflected as most satisfied. Students used this scale to rank their level of contentment with the colour of their teeth, smile in photographs and how much their occupation has motivated their oral health.

Data analysis was done using descriptive statistics such as percentage, cross tabulation etc. via $21^{\text {st }}$ version of SPSS. $0.5 \%$ was established as the level of significance.

\section{RESULTS:}

$79.05 \%(166 / 210)$ students responded to the study and completed the survey form. Figure 1 shows the male to female ratio in the participants and Table 1 illustrates the age range and mean age of the students participated in the study. Table 2 reveals that $91.6 \%$ respondents were assertive while smiling public. Conversely $32.5 \%$ were shy to show their teeth while smiling at public places. $55.4 \%$ students felt that their side pose looked better from front pose in photographs. $56.6 \%$ students preferred to have a celebrity like smile. $77.7 \%, 87.3 \%$ and $24.7 \%$ students were not satisfied with their tooth colour, contour and gums respectively.

Moreover, when they were inquired about gratification related to incisal display, proportion of gums visible and dimensions of teeth, only $7.8 \%$ and $8.4 \%$ participants were appeased with the incisal display and gum show at smiling respectively (Table 3 and 4). 60.2\% and 54.8\% applicants were happy with the length and breadth of their teeth respectively. (Table 5 and 6 )

Table 7 shows that only $46.4 \%$ candidates were pleased with the form of their teeth. Table 8 shows the mean and median of 4 questions that candidates were asked to record answers using a numeric scale from 0 to 10 . Applicants contented with their teeth colour counted $16.9 \%$ only and $32.5 \%$ were completely satisfied with their smile in photographs (scored 10). The students responded unevenly on how much dental education motivated their oral health behaviour, $31.9 \%$ individuals observed that dental education has exerted $100 \%$ inspiration on their oral hygiene performance.

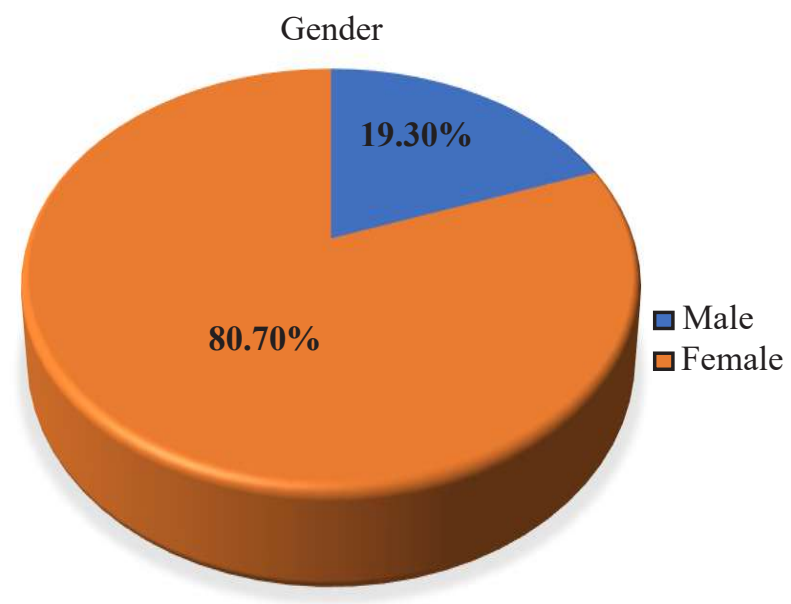

Fig 1: Gender distribution

\begin{tabular}{|c|c|}
\hline \multicolumn{2}{|c|}{ Age } \\
\hline Minimum & 16 \\
\hline Maximum & 26 \\
\hline Mean & 20.44 \\
\hline Std. Deviation & 1.523 \\
\hline
\end{tabular}

Table 1: Age distribution

\section{DISCUSSION:}

This survey was conducted to validate the self-concept of undergraduate dental students at Isra University, related to their own smile and dental appearance.

Multiple factors including age, gender, social circle, socioeconomic factors and media influence the individual's insights concerning their smile and dental appearance in a number of ways ${ }^{16,17}$. Therefore, to monitor the selfapprehension of a community is a great challenge.

Our analysis presented that, $91.6 \%$ candidates were happy with their smile while smiling in open while $69.9 \%$ individuals preferred other's smile at their owns. Similarly, in a survey carried out by Azodo CC et $\mathrm{al}^{18}$; more than three- 
Farzana Memon, Salwa Memon, Muhammad Muslim Khahro, Abdul Salam Memon

\begin{tabular}{|c|c|c|c|c|c|c|}
\hline \multirow{2}{*}{$\begin{array}{c}\text { Questions } \\
\text { Gender }\end{array}$} & \multicolumn{2}{|c|}{ Yes } & \multicolumn{2}{|c|}{ No } & \multicolumn{2}{|c|}{ Total } \\
\hline & Male & Female & Male & Female & Yes & No \\
\hline Do you feel confident while smiling? & $\begin{array}{c}28 \\
(18.4 \%)\end{array}$ & $\begin{array}{c}124 \\
(81.6 \%)\end{array}$ & $\begin{array}{c}4 \\
(28.6 \%)\end{array}$ & $\begin{array}{c}10 \\
(71.4 \%)\end{array}$ & $\begin{array}{c}152 \\
(91.6 \%)\end{array}$ & $\begin{array}{c}14 \\
(8.4 \%)\end{array}$ \\
\hline Do you cover your mouth with your hand while smiling? & $\begin{array}{c}2 \\
(3.7 \%)\end{array}$ & $\begin{array}{c}52 \\
(96.3 \%)\end{array}$ & $\begin{array}{c}30 \\
(26.8 \%)\end{array}$ & $\begin{array}{c}82 \\
(73.2 \%)\end{array}$ & $\begin{array}{c}54 \\
(32.5 \%)\end{array}$ & $\begin{array}{c}112 \\
(67.5 \%)\end{array}$ \\
\hline $\begin{array}{l}\text { Do you feel that your face's side pose looks better in } \\
\text { photograph? }\end{array}$ & $\begin{array}{c}19 \\
(20.7 \%)\end{array}$ & $\begin{array}{c}73 \\
(79.3 \%)\end{array}$ & $\begin{array}{c}13 \\
(17.6 \%)\end{array}$ & $\begin{array}{c}61 \\
(82.4 \%)\end{array}$ & $\begin{array}{c}92 \\
(55.4 \%)\end{array}$ & $\begin{array}{c}74 \\
(44.6 \%)\end{array}$ \\
\hline Do you think someone has a better smile than yours? & $\begin{array}{c}24 \\
(20.7 \%) \\
\end{array}$ & $\begin{array}{c}92 \\
(79.3 \%) \\
\end{array}$ & $\begin{array}{c}8 \\
(16.0 \%) \\
\end{array}$ & $\begin{array}{c}42 \\
(84.0 \%) \\
\end{array}$ & $\begin{array}{c}116 \\
(69.9 \%) \\
\end{array}$ & $\begin{array}{c}50 \\
(30.1 \%) \\
\end{array}$ \\
\hline $\begin{array}{l}\text { Are your eyes drawn to the model's smile, when you read } \\
\text { a fashion magazine? }\end{array}$ & $\begin{array}{c}13 \\
(13.8 \%)\end{array}$ & $\begin{array}{c}81 \\
(86.2 \%)\end{array}$ & $\begin{array}{c}19 \\
(26.4 \%)\end{array}$ & $\begin{array}{c}53 \\
(73.6 \%)\end{array}$ & $\begin{array}{c}94 \\
(56.6 \%)\end{array}$ & $\begin{array}{c}72 \\
(43.4 \%) \\
\end{array}$ \\
\hline $\begin{array}{l}\text { Do you feel any defects in your teeth or gums, when you } \\
\text { look at your smile in the mirror? }\end{array}$ & $\begin{array}{c}17 \\
(14.0 \%)\end{array}$ & $\begin{array}{c}105 \\
(86.0 \%)\end{array}$ & $\begin{array}{c}15 \\
(34.9 \%)\end{array}$ & $\begin{array}{c}29 \\
(65.1 \%)\end{array}$ & $\begin{array}{c}122 \\
(73.5 \%)\end{array}$ & $\begin{array}{c}44 \\
(26.5 \%)\end{array}$ \\
\hline Do you desire to have whiter teeth? & $\begin{array}{c}21 \\
(19.8 \%)\end{array}$ & $\begin{array}{c}85 \\
(80.2 \%)\end{array}$ & $\begin{array}{c}11 \\
(18.3 \%)\end{array}$ & $\begin{array}{c}49 \\
(81.7 \%)\end{array}$ & $\begin{array}{c}106 \\
(63.9 \%)\end{array}$ & $\begin{array}{c}60 \\
(36.1 \%)\end{array}$ \\
\hline Are you satisfied with the way your gums look? & $\begin{array}{c}26 \\
(20.2 \%) \\
\end{array}$ & $\begin{array}{c}103 \\
(79.8 \%) \\
\end{array}$ & $\begin{array}{c}6 \\
(16.2 \%) \\
\end{array}$ & $\begin{array}{c}31 \\
(83.8 \%) \\
\end{array}$ & $\begin{array}{c}129 \\
(77.7 \%) \\
\end{array}$ & $\begin{array}{c}37 \\
(22.3 \%) \\
\end{array}$ \\
\hline Do you like the shape of your teeth? & $\begin{array}{c}22 \\
(17.6 \%) \\
\end{array}$ & $\begin{array}{c}103 \\
(82.4 \%) \\
\end{array}$ & $\begin{array}{c}10 \\
(24.4 \%) \\
\end{array}$ & $\begin{array}{c}31 \\
(75.6 \%) \\
\end{array}$ & $\begin{array}{c}125 \\
(75.3 \%) \\
\end{array}$ & $\begin{array}{c}41 \\
(24.7 \%) \\
\end{array}$ \\
\hline $\begin{array}{l}\text { Do you idealize any model's smile in magazines and } \\
\text { desire to have a smile as pretty as theirs? }\end{array}$ & $\begin{array}{c}30 \\
(20.7 \%)\end{array}$ & $\begin{array}{c}115 \\
(79.3 \%)\end{array}$ & $\begin{array}{c}2 \\
(9.5 \%)\end{array}$ & $\begin{array}{c}19 \\
(90.5 \%)\end{array}$ & $\begin{array}{c}145 \\
(87.3 \%)\end{array}$ & $\begin{array}{c}21 \\
(12.7 \%)\end{array}$ \\
\hline
\end{tabular}

Table 2: Results of the combined questions concerning the satisfaction with the own teeth and smile

\begin{tabular}{|c|c|c|c|}
\hline Teeth visible at smiling? & Male & Female & Total \\
\hline Too many & 12 & 52 & $64(38.6 \%)$ \\
\hline Too few & 18 & 71 & $89(53.6 \%)$ \\
\hline Normal & 2 & 11 & $13(7.8 \%)$ \\
\hline
\end{tabular}

Table 3: Self-perception of students regarding teeth visible during smiling

\begin{tabular}{|c|c|c|c|}
\hline $\begin{array}{l}\text { Do you think teeth } \\
\text { too long or too short? }\end{array}$ & Male & Female & Total \\
\hline Too long & 4 & 30 & $34(20.5 \%)$ \\
\hline Too short & 6 & 26 & $32(19.3 \%)$ \\
\hline Normal & 22 & 78 & $100(60.2 \%)$ \\
\hline
\end{tabular}

Table 5: Self-perception of students concerning teeth length during smiling

\begin{tabular}{|c|c|c|c|}
\hline $\begin{array}{c}\text { Do you think teeth too } \\
\text { square or too round? }\end{array}$ & Male & Female & Total \\
\hline Too long & 11 & 61 & $72(43.4 \%)$ \\
\hline Too short & 7 & 10 & $17(10.2 \%)$ \\
\hline Normal & 14 & 63 & $77(46.4 \%)$ \\
\hline
\end{tabular}

Table 7: Self-perception of students concerning teeth shape during smiling

\begin{tabular}{|c|c|c|c|}
\hline Gums visible at smiling? & Male & Female & Total \\
\hline Too much & 8 & 16 & $24(14.5 \%)$ \\
\hline Too little & 23 & 105 & $128(77.1 \%)$ \\
\hline Normal & 1 & 13 & $14(8.4 \%)$ \\
\hline
\end{tabular}

Table 4: Self-perception of students regarding gums visible while smiling

\begin{tabular}{|c|c|c|c|}
\hline $\begin{array}{l}\text { Do you think teeth too } \\
\text { wide or too narrow? }\end{array}$ & Male & Female & Total \\
\hline Too long & 8 & 39 & $47(28.3 \%)$ \\
\hline Too short & 4 & 24 & $28(16.9 \%)$ \\
\hline Normal & 20 & 71 & $91(54.8 \%)$ \\
\hline
\end{tabular}

Table 6: Self-perception of students concerning teeth width during smiling

\begin{tabular}{|l|c|c|}
\hline \multicolumn{1}{|c|}{ Score (0-10) } & Mean & Median \\
\hline Gratification concerning your teeth colour? & 7.52 & 8.00 \\
\hline $\begin{array}{l}\text { Level of gratification related to your smile } \\
\text { in photographs? }\end{array}$ & 7.92 & 8.00 \\
\hline $\begin{array}{l}\text { How much your occupation has motivated } \\
\text { your oral hygiene? }\end{array}$ & 8.40 & 9.00 \\
\hline
\end{tabular}

Table 8: Mean and median of dental student's self-perception regarding scored questions 
quarters $(79.4 \%)$ were appeased with their dental look.

Whereas Silva GDCD et $\mathrm{al}^{7}$, revealed in his study done at Brazilian students that $92 \%$ of them were gratified with their smile while $90 \%$ admired other people's smile. The reason behind this is that nowadays mass media is playing a great role in bringing smile beauty standards forward, which is mostly effecting the females and teenagers. Majority of the people thus seeking orthodontic treatment for aesthetic reasons are usually females and teenagers or young adults. ${ }^{19}$

A study ${ }^{7}$ conducted in the year 2012 had similar findings as ours that showed though females were more pleased with their smile then males yet they admired to have a better and a superstar like smile. Conversely, few more studies ${ }^{17,20,21}$ showed that females tends to be more unhappy with their smiles as compared to males. In another study ${ }^{22}$ male and female participants had equal gratification level regarding tooth colour, whereas in terms of occlusion and teeth dimensions females were less contented as compared to males.

It's generally observed that females are more beauty conscious whether it is aesthetic implications of missing teeth ${ }^{23}$ or any scar resulting from some physical injury ${ }^{24}$.

The findings of our study showed that $77.7 \%$ individuals desired to have lighter teeth. The findings of Tortopidis D et $\mathrm{al}^{14}$ and Thiyagarajan $\mathrm{A}$ et $\mathrm{al}^{25}$, were consistent with our study while the findings of Carlsson et $\mathrm{al}^{26}$ contradicted our study and found that non dental students urged to have lighter teeth as compared to dentists.

The traditional sensation of tooth whitening has already flourished in many countries. In US, 34\% of total population is unhappy with their tooth colour. ${ }^{27}$ In fact, current tradition dictates not only the demand for a healthy mouth but a perfect smile as well ${ }^{28}$.

Our study revealed that $87.3 \%$ respondents were gratified with their tooth form which was consistent with the study ${ }^{7}$ conducted in the year 2012. Additional studies must be conducted in this area keeping in mind the needs and difficulties, professionals face while planning an aesthetic treatment.

\section{CONCLUSION:}

Within the limitations of this study, it is concluded that majority of the dental students were gratified with their selfapprehension related to their own smile and dental look. Females though more satisfied with the form and dimensions of the teeth, desired to have even better smile in terms of tooth colour because they are more beauty conscious and they easily and readily get touched and inspired by other's smile.

Dental Students have more knowledge of dental aesthetics as compared to a lay man and as the year of study progresses, their knowledge related to smile aesthetic increases. Hence, dental education and awareness has positive attitude on or oral hygiene behaviour. It is also very important for the practitioners to understand the patient's self-concept of their own smile and dental appearance because lack of communication between them can lead to patient discontentment even if the treatment planned and executed according to ideal smile aesthetic standards.

\section{REFERENCES:}

1. Omar H and Tai YT. Perception of smile esthetics among dental and non dental students. J Edu Ethic Dent. July-Dec 2014; 4(2): 54-60.

2. Van der Geld P, Oosterveld P, Van Heck G et al. Smile attractiveness. Angle Orthod. 2007; 77(5): 759-65

3. Selected aspects of the art and science of facial esthetics. Seminars in orthodontics. Netherlands: Elsevier; 1995.

4. Kerns LL, Silveira AM, Kerns DG et al. Esthetic preference of the frontal and profile views of the same smile. J Esthet Dent. 1997; 9: 76-85.

5. Goldstein RE. Study of need for esthetics in dentistry. J Prosthet Dent. 1969; 21: 589-98.

6. Miller AG. Role of physical attractiveness in impression formation. Psychon Scien. 1970; 241-3.

7. Silva GDCD, Castilhos EDD, Masotti AS et al. Dental esthetic self perception of Brazilian dental students. RSBO. Oct-Dec 2012; 9(4): 375-81.

8. Coffield KD, Phillips C, Brady M, Roberts MV et al. The psychosocial impact of developmental dental defects in people with hereditary amelogenesis imperfecta. J Am Dent Assoc. 2005; 136(5): 620-30.

9. Albino JE, Tedesco LA, Conny DJ. Patient perceptions of dental-facial esthetics: Shared concerns in orthodontics and prosthodontics. J Prosthet Dent. 1984; 52: 9-13.

10. Proffit W, Fields H, Sarver D. Contemporary orthodontics. St. Louis, Mo.: Mosby Elsevier; 2007; p. 12.

11. Alarcon GP and Ocampo R. "Dental Aesthetic and Self Confidence among Filipino Adolescents". The Bedan Journal of Psychology 1 (2016): 7-15

12. Moskowitz ME, Nayyar A. Determinants of dental esthetics: A rational for smile analysis and treatment. Compend Contin Educ Dent. 1995; 16: 1164-66.

13. Saffarpour A, Ghavam M et al. J Dent (Tehran). Mar 2016; 13(2): 85-91.

14. Tortopidis D, Hatzikyriakos A, Kokoti M, Menexes G et al. Evaluation of the relationship between subjects' perception and professional assessment of esthetic treatment needs. J Esthet Restor Dent. 2007; 19(3): 154-63.

15. Omar H, Tai YT. J Education and Ethics Dent. 2014; 4 (2): 54-60.

16. Jornung $\mathrm{J}$ and Fardal O. Percept ions of patients' smiles: a comparison of patients' and dentists' opinions. J Am Dent Assoc. 2007; 138(12): 1544-53.

17. Vallittu PK, Vallittu ASJ, Lassila VP. Dental aesthetics - a survey of attitudes in different groups of patients. J Dent. 1996; 24(5): 335-8.

18. Azodo CC, Ogbomo AC. Self-Evaluated Dental Appearance Satisfaction among Young Adults. Ann Med Health Sci Res. 2014; 4(4): 603-607.

19. Marques LS, Pordeus IA, Ramos-Jorge ML et al. Factors 
associated with the desire for orthodontic treatment among Brazilian adolescents and their parents. BMC Oral Health. 2009; 9: 34.

20. Flores-Mir C, Silva E, Barriga MI, Lagravere MO et al. Lay person's perception of smile aesthetics in dental and facial views. J Orthod. 2004; 31(3): 204-9.

21. Shulman JD, Maupomé G, Clark DC, Levy SM. Perceptions of desirable tooth color among parents, dentists and children. J Am Dent Assoc. 2004; 135(5): 595-604.

22. Shahrani IA. Self perception of personal dental appearance among students of King Khaled University Abha, Saudi Arabia. Eurp J Gen Dent. 2014; 3(3): 181-84.

23. Gerritsen AE, Sarita P, Witter DJ, Kreulen CM et al. Esthetic perception of missing teeth among a group of Tanzanian adults. Int J Prosthod. 2008; 21(2): 169-73.

24. Akarslan ZZ, Sadik B, Erten H, Karabulut E. Dental esthetic satisfaction, received and desired dental treatments for improvement of esthetics. Indian J Dent Res. 2009; 20(2): 195-200.
25. Thiyagarajan A, Kumar D. Dental Esthetics: Perception from Future Dental Professionals. Acta Scientific Dental Sciences. 2018; 2(4): 03-05.

26. Carlsson GE, Wagner IV, Odman P, Ekstrand K et al. An international comparative multicenter study of assessment of dental appearance using computer-aided image manipulation. Int J Prosthod. 1998; 11(3): 246-54.

27. Odioso LL, Gibb RD, Gerlach RW. Impact of demographic, behavioural, and dental care utilization parameters on tooth color and personal satisfaction. Compend Contin Educ Dent. 2000; 29: 35-41.

28. Joiner A. Tooth colour: a review of the literature. J Dent. 2004; 32: 3-12. 